\title{
Report on Magnetic Gradient Survey at Three Caddo Sites in East Texas
}

Duncan P. McKinnon

Department of Anthropology, University of Central Arkansas

Follow this and additional works at: https://scholarworks.sfasu.edu/ita

Part of the American Material Culture Commons, Archaeological Anthropology Commons, Environmental Studies Commons, Other American Studies Commons, Other Arts and Humanities Commons, Other History of Art, Architecture, and Archaeology Commons, and the United States History Commons

Tell us how this article helped you.

This Article is brought to you for free and open access by the Center for Regional Heritage Research at SFA ScholarWorks. It has been accepted for inclusion in Index of Texas Archaeology: Open Access Gray Literature from the Lone Star State by an authorized editor of SFA ScholarWorks. For more information, please contact cdsscholarworks@sfasu.edu. 
Report on Magnetic Gradient Survey at Three Caddo Sites in East Texas

Creative Commons License

(C) $(1) \Theta$

This work is licensed under a Creative Commons Attribution-NonCommercial 4.0 International License 


\section{Report on Magnetic Gradient Survey at Three Caddo Sites in East Texas}

Duncan P. McKinnon

\section{Introduction}

The use of magnetic gradient at Caddo sites located throughout the Caddo people's ancestral lands within the current areas of east Texas, southwest Arkansas, northeast Louisiana, and eastern Oklahoma has been very successful in the elucidation and mapping of the distributional characteristics of buried cultural features (see Perttula et al. 2008; Hammerstedt et al. 2010; Walker and McKinnon 2012). January 2016 surveys conducted at three Caddo sites in East Texas (41CE475, 41CE476, and 41CE477) add to this growing corpus of remote sensing spatial data (Figure 1). The survey work was conducted in order to assess the nature of sub-surface preservation in different environmental and historical contexts and map the distribution of geophysical anomalies attributed to Caddo occupations. The following article presents results and preliminary interpretations.

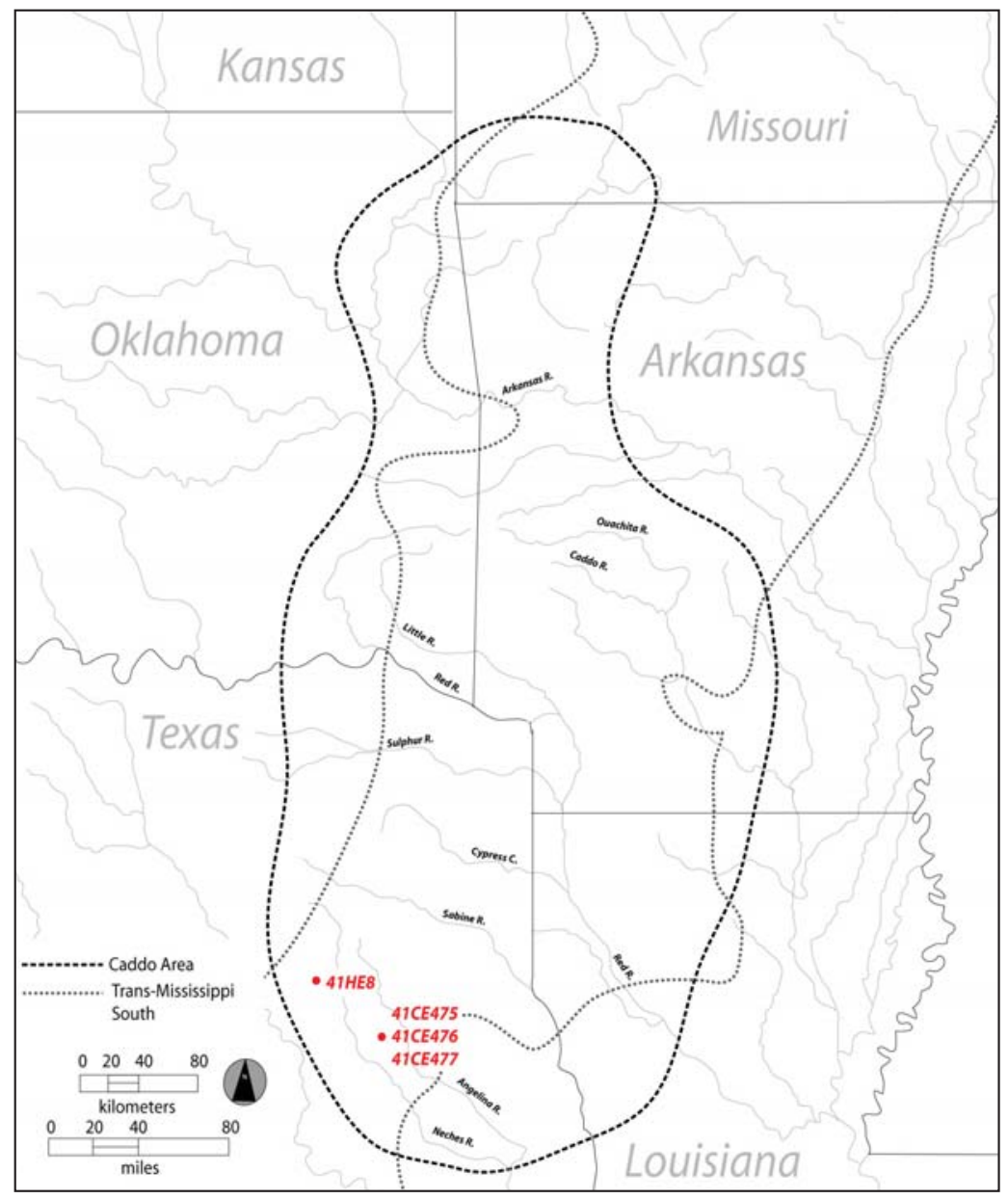

Figure 1. The Caddo Archaeological Area with the location of the three surveyed sites in Cherokee County, Texas. 


\section{Magnetic Gradient}

Magnetic gradient interpretations discussed herein are developed using a combination of inductive and deductive approaches. An inductive approach has roots in satellite and aerial image interpretation with the recognition that geometric shapes, relative sizes, and systematic repetitions of image objects can form interpretable patterns (Wilson 2000). When anomalies in a geophysical dataset resemble patterns of regular geometric shapes, it can be induced that they are of probable cultural origin. A deductive approach utilizes known physical properties of the subsurface matrix (artifacts, features, sediments, and soils recorded during excavation) to deduce how instrument sensors might respond and thus certain interpretative deductions can be made about the nature of anomalies revealed in the data. For example, thermoremanent magnetism is the result of highly heated burning events, which can produce an anomaly composed of stronger magnetic values (see Kvamme 2006, 2008). Anomalies of medium to high magnetic value may be deduced as being generated by a hearth, kiln, or burned house, for example. A soil matrix that has been magnetically enriched through pedogenesis (induced magnetism and magnetic susceptibility) can also produce anomalies containing stronger magnetic values than those in the surrounding matrix (see Kvamme 2006, 2008). Several low to medium magnetic signatures identified within or around a structure may be deduced as being pits. Highest magnetic values are typically related to ferrous metal debris buried close to the surface, which can generate anomalies of extreme magnitude. Magnetic values collected by magnetic gradient instruments are recorded in nanotesla (nT; $10^{9}$ tesla).

The recent East Texas magnetic gradient surveys were conducted using a Bartington Grad 601-2 fluxgate gradiometer (Bartington and Chapman 2004). The Grad 601-2 is a vertical component fluxgate gradiometer containing two cylindrical sensor assemblies. Each cylindrical sensor assembly contains two mounted sensors with a 1-meter vertical spatial separation that measure the vertical component of the magnetic field. Since magnetic strength decreases with the cube of distance $\left(1 / \mathrm{d}^{3}\right)$, the lower sensor is more sensitive to subsurface readings whereas the opposite upper sensor is more sensitive to Earth's magnetic field (Clark 1996:78). Simple differencing of the two readings removes the effects of the latter. Given that the Bartington instrument offers a vertical sensor separation of 1-meter, the sensitivity of the instrument is greatly increased and subsurface magnetic features more pronounced when compared to gradiometers with a shorter sensor separation (Bartington and Chapman 2004).

Data at the three sites were collected within established 20 x 20 meter grids where a survey tape was pulled taut along each baseline and non-metallic pin flags were placed along baselines to guide the surveyor (Figure 2). White non-metallic pin flags were set at every odd meter with a blue nonmetallic pin flag set on every fifth meter. The established non-metallic pin flags were used as transect (Y) collection guidelines in order to maintain 0.5-meter spacing along each grid baseline (X). Collection spacing along each transect $(\mathrm{Y})$ was set to 0.125 -meter spacing (8 samples per meter) and regulated using a focused and practiced walking pace of 1.3 meters/second. Data were collected using a zigzag pattern.

\section{Magnetic Gradient Survey Results}

The survey work was conducted at the Cherokee County sites from January 15 to 18,2016 . They are located within the Bowles Creek drainage in the middle Neches River basin south of Rusk, Texas. Recent analyses of ceramics from the spatially proximate sites indicate they were each occupied during the Historic Caddo period Allen phase (ca. A.D. 1650-1800) (Perttula et al. 2016; Perttula and Stingley 2016a, 2016b, 2017). 


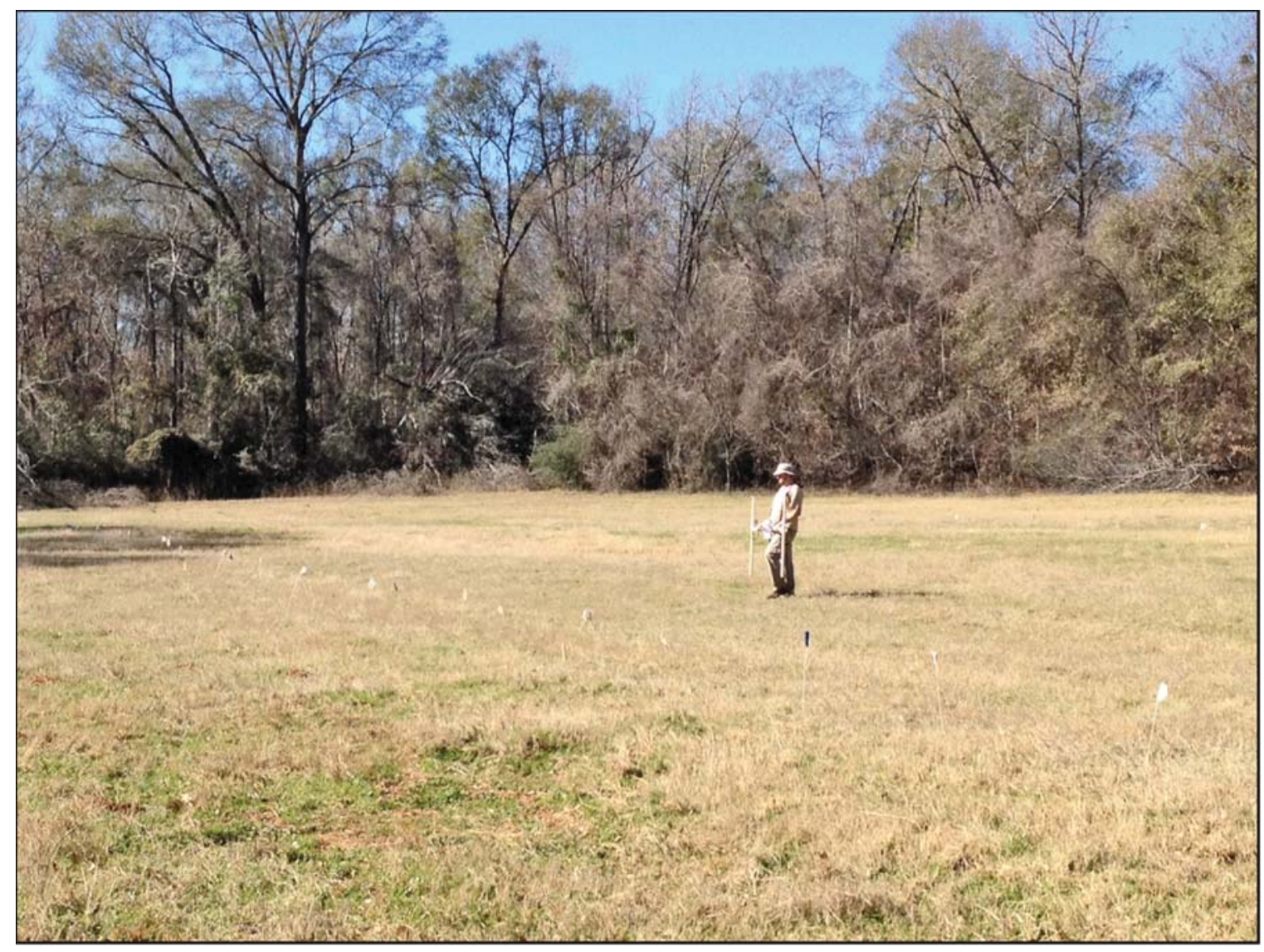

Figure 2. Data collection with a Bartington Grad 601-2 fluxgate gradiometer at 41CE475. White and blue non-metallic pin flags were used to guide surveyor.

\section{Bowles Creek Site (41CE475)}

The Bowles Creek site is situated a few meters north of Bowles Creek within the floodplain on a low rise. At the time of the survey, the surface was highly disturbed as a result of significant gopher activity. A small area $(40 \mathrm{~m} \times 60 \mathrm{~m})$ of the site was surveyed to determine the feasibility of identifying subsurface magnetic gradient cultural features, despite evidence of significant bioturbation. The survey area was situated approximately $30 \mathrm{~m}$ north of the creek and toward the eastern extent of the site (Figure 3).

As anticipated, results reveal several linear magnetic signatures that are likely associated with subsurface bioturbation. However, patterns suggest the presence of several intact cultural features (see Figure 3). For example, the burned remains of two possible structures, each approximately $5 \mathrm{~m}$ in diameter, are interpreted along with several isolated possible post holes or post molds scattered throughout the site. Archaeological investigations document the presence of wood charcoal, burned clay, and other residential debris including possible cooking pit features that demonstrate domestic activity (Perttula et al. 2016). Additionally, a long linear high magnetic feature in the southwest portion of the survey area is interpreted as the remains of an historic trench, the function of which is not known. 


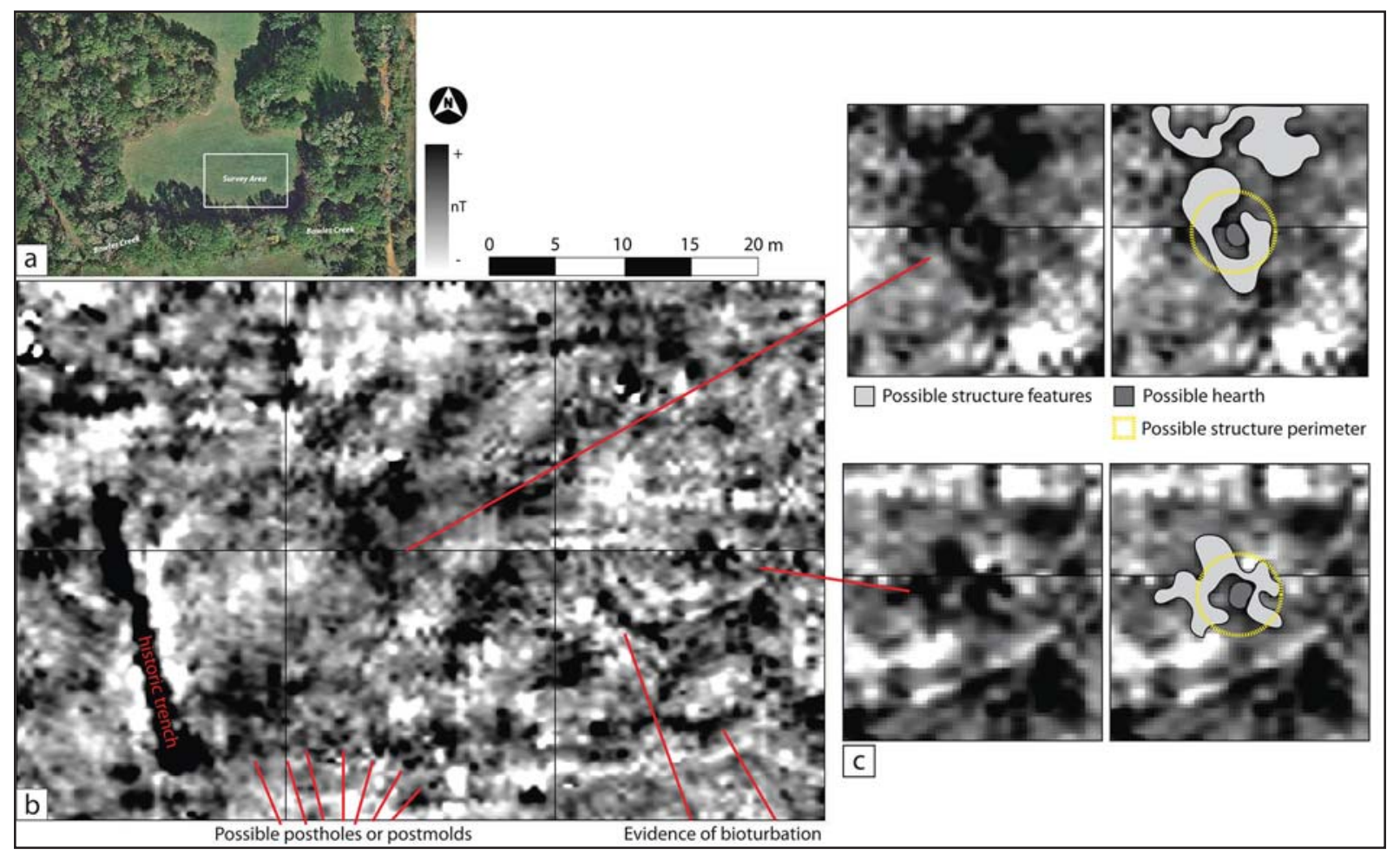

Figure 3. Magnetic gradient results from the Bowles Creek (41CE475) site: (a) Location of survey area and Bowles Creek, (b) magnetic gradient results, and (c) two anomalies of possible burned structure remains.

\section{Peach Orchard Site (41CE477)}

The Peach Orchard site is located about 300 meters northeast of the Bowles Creek site and is situated on an upland landform above the Bowles Creek drainage. Portions of the site are heavily eroded. The magnetic gradient survey focused on a small area $(40 \mathrm{~m} \mathrm{x} 60 \mathrm{~m})$ that is less disturbed and where a recent surface collection recovered more than 2100 ceramic sherds (Perttula and Stingley 2016b). The survey area was situated a few meters north of the county road (Figure 4).

Results reveal the remains of a possible burned structure centered within the survey area. Three high magnetic "circles" define the eastern side, which may represent structure remains. Several isolated high magnetic anomalies throughout the survey area might represent the location of pits. A concentration of metal in the southeast corner of the survey area is the remains of an historic occupation; several mid- $19^{\text {th }}$ to early $20^{\text {th }}$ century historic artifacts had been collected from the surface collection grid in this part of the site (Perttula and Stingley 2016b:Table 6). 


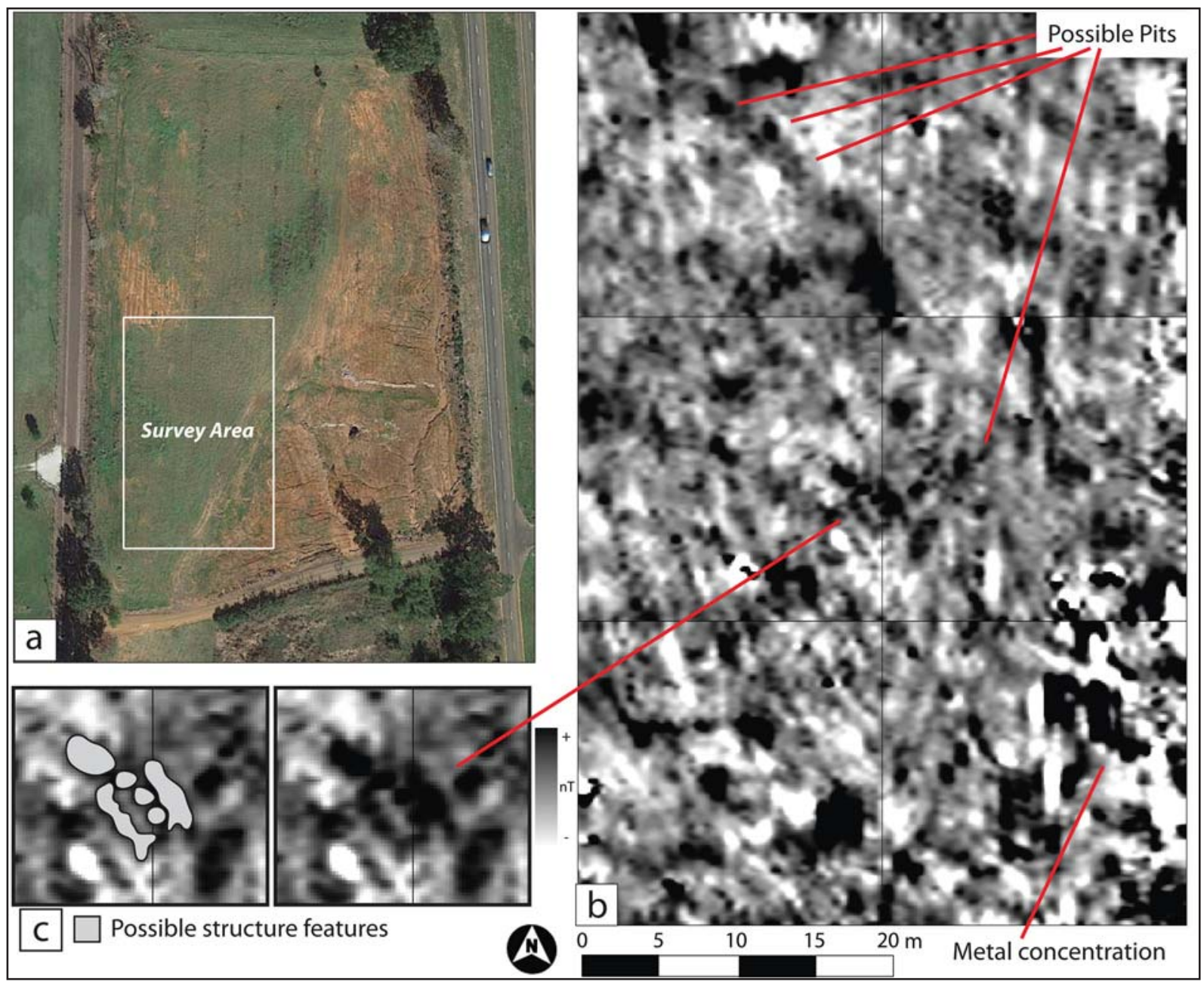

Figure 4. Magnetic gradient results from the Peach Orchard (41CE477) site: (a) Location of survey area, (b) magnetic gradient results, and (c) remains of a possible burned structure.

\section{Cornfield Site (41CE476)}

The Cornfield site is in an open pasture located on a terrace between Bowles Creek and Turkey Creek. It is named the Cornfield site because it was the location of a 1870s Anglo-American agricultural tract. It is located approximately 600 meters north of the Peach Orchard site. While the site has a long history of agricultural use and current observations reveal high levels of bioturbation, three anomalies indicate the possibility of the remains of burned and buried structures.

Three possible structures are interpreted (Figure 5). A small circular anomaly with an isolated high magnetic feature is located in the western part of the survey area and is approximately $2.5 \mathrm{~m}$ in diameter. The possible structure is adjacent to a large high magnetic area. In the northern part of the survey area, a large anomaly is interpreted as a possible rectangular structure containing a centralized hearth or other high magnetic feature. To the east, a cluster of high magnetic values suggests the presence of a third structure at the site. 


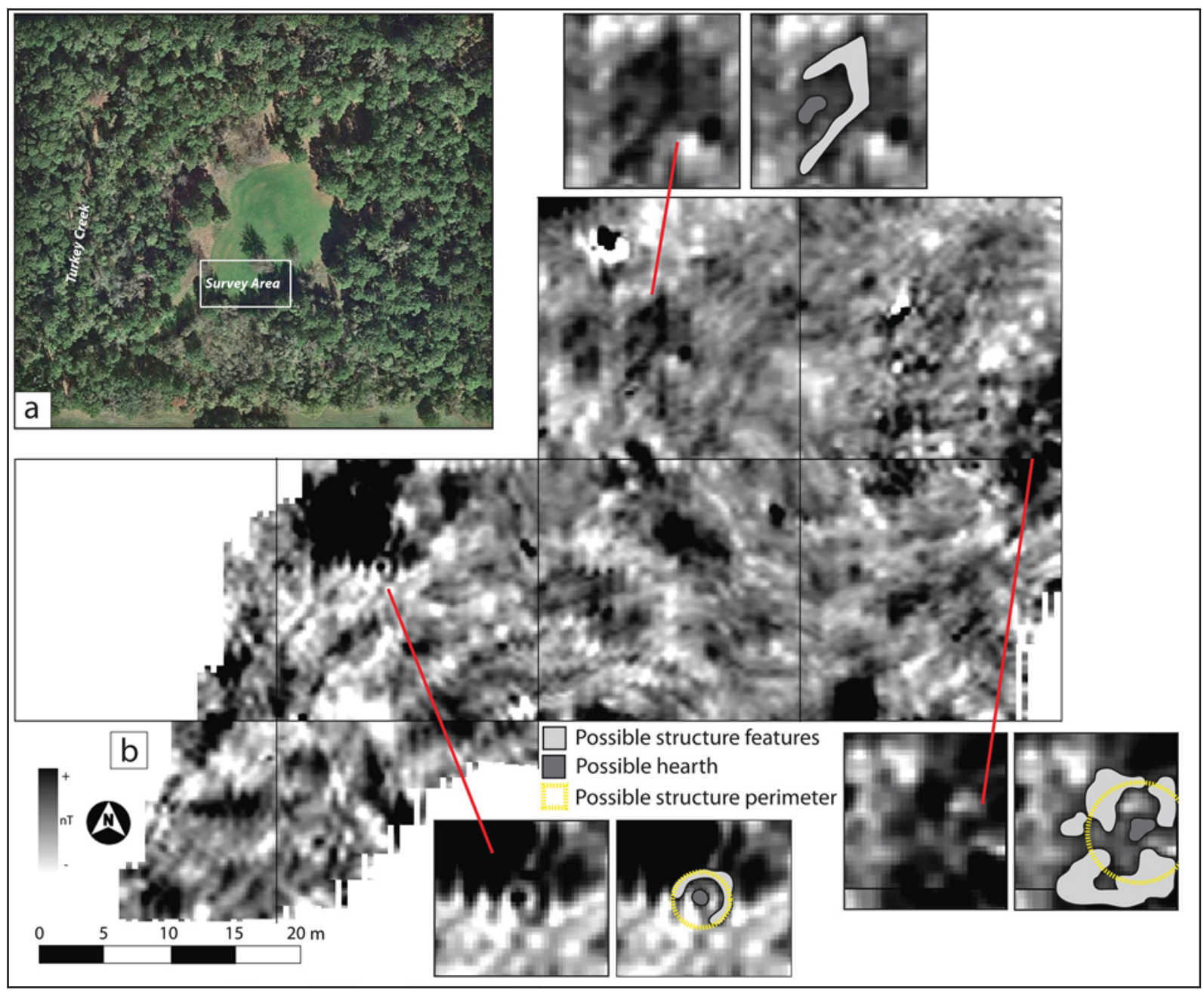

Figure 5. Magnetic gradient results from the Cornfield (41CE476) site: (a) Location of survey area, (b) magnetic gradient results with interpretations of three possible structures.

\section{References Cited}

Bartington, G. and C. E. Chapman

2004 A High-stability Fluxgate Magnetic Gradiometer for Shallow Geophysical Survey Applications. Archaeological Prospection 11:19-34.

Clark, A.

1996 Seeing Beneath the Soil: Prospecting Methods in Archaeology (New Edition). Revised Edition. B. T. Batsford Ltd., London, England.

Hammerstedt, S. W., A. L. Regnier, and P. C. Livingood

2010 Geophysical and Archaeological Investigations at the Clement Site, A Caddo Mound Complex in Southeastern Oklahoma. Southeastern Archaeology 29(2):279-291.

Kvamme, K. L.

2006 Magnetometry: Nature's Gift to Archaeology. In Remote Sensing in Archaeology, An Explicitly North American Perspective, edited by J. K. Johnson, pp. 205-233. University of Alabama Press, Tuscaloosa, Alabama.

2008 Remote Sensing Approaches to Archaeological Reasoning: Pattern Recognition and Physical Principles. In Archaeological Concepts for the Study of the Cultural Past, edited by A. P. Sullivan, pp. 65-84. The University of Utah Press, Salt Lake City. 
Perttula, T. K. and K. Stingley

2016a Additional Material Culture Remains from the Bowles Creek Site (41CE475) in Cherokee County, Texas. Journal of Northeast Texas Archaeology 67:7-14.

2016b Analysis of the Recovered Artifacts from the Controlled Surface Collection at the Peach Orchard Site (41CE477), Cherokee County, Texas. Journal of Northeast Texas Archaeology 70:91-110.

2017 Renewed Archaeological Investigations at the Bowles Creek (41CE475), Cornfield (41CE476), and Peach Orchard (41CE477) Sites in the Bowles Creek Valley, Cherokee County, Texas. Journal of Northeast Texas Archaeology 71:1-21.

Perttula, T. K., K. Stingley, and M. Walters

2016 Historic Caddo Archaeological Sites in Cherokee County, Texas. Journal of Northeast Texas Archaeology 65:1-24.

Perttula, T. K., C. P. Walker, and T. C. Schultz

2008 A Revolution in Caddo Archaeology: The Remote Sensing and Archaeological View from the Hill Farm Site (41BW169) in Bowie County, Texas. Southeastern Archaeology 27(1):93-107.

Walker, C. P. and D. P. McKinnon

2012 Exploring Prehistoric Caddo Communities through Archaeogeophysics. In The Archaeology of the Caddo, edited by T. K. Perttula and C. P. Walker, pp. 177-208. University of Nebraska Press, Lincoln.

Wilson, D. R.

2000 Air Photo Interpretation for Archaeologists. St. Martin's Press, New York. 